\title{
Ireland's National Forum on Europe: Elite Deliberation Meets Popular Participation
}

\author{
JOHN O'BRENNAN
}

University of Limerick, Ireland

(Received March 2003; final version March 2004)

\begin{abstract}
In the wake of the rejection of the Nice Treaty by the electorate in June 2001, the Irish government moved to establish a National Forum on Europe, which was to be the arena for a new socially inclusive and highly visible dialogue on issues arising out of Irish membership of the European Union (EU). The Forum represented an entirely novel approach to consideration of European affairs in Ireland and, as such, an acknowledgement that the old era of 'permissive consensus' on EU issues had gone. This article utilises insights from deliberative democracy to analyse the new Irish discourse on Europe that the Forum has helped articulate. The analysis suggests that the Forum has successfully widened the scope and substance of Irish attitudes to Europe. Most importantly, it has helped shift the emphasis from functional costbenefit considerations related to receipts from the CAP and structural funding, to more broad-based and 'mainstream' consideration, which encompass the broad ambit of issues connected to the future direction of the European integration project. The article also argues that the Forum has engaged a wider and more inclusive group of societal actors in European debate. Thus, Irish EU debate is no longer concentrated among traditional elites - the political parties, trade unions, business groups and academics. Finally, the article assesses the extent to which the Forum has encouraged greater popular participation in EU debate.
\end{abstract}

KEY WORDS: European integration, Ireland and the EU, popular participation, deliberative democracy, democratic deficit, Nice Treaty

Correspondence Address: John O’Brennan, Department of Politics and Public Administration, University of Limerick, Limerick, Ireland; Email: John.OBrennan@ul.ie 


\section{Introduction}

Modelled on the New Ireland Forum (NIF) and its successor, the Forum for Peace and Reconciliation, and emerging as one element of the response to the rejection by the electorate of the Nice Treaty in June 2001, the National Forum on Europe (NFOE) was set up with the aim of encouraging the widest possible societal dialogue on Europe in Ireland. The objective set out by its Chairman at its launch was to "undertake a wide-ranging analysis of what the European Union has meant to Ireland, to examine issues concerned with the historic enlargement now in prospect, and to inform the Government, through debate, as to how the Irish people - those at the centre of the debate - see the future development of Europe in a way which will suit Irish interests". ${ }^{1}$ This encompassed a number of key objectives: to bridge the gap between political elites and the citizens of the Republic on European issues; to make 'Europe' more intelligible to the public; to make the EU more visible within national political debate; and to address concerns regarding enlargement and Ireland's future in an enlarged Union. Whilst some saw the Forum as a short-term and cynical measure on the part of a government which had for the first time lost a European referendum and needed to be seen to be doing something in response, others welcomed the prospect of a comprehensive and spirited national conversation on Europe.

This article analyses the work of the Forum from the perspective of popular participation and deliberative democracy. It seeks to examine the contributions and arguments put forward by the participants, to analyse the issues that most preoccupied the members, to investigate the proceedings of the public sessions of the Forum, and to weigh up the extent to which the Forum really contributed to re-constituting European debate in Ireland on a more inclusive basis. It begins by examining Ireland's changing relationship with the European Union, the dramatic impact of the failure of the Nice Treaty referendum in 2001 and the context in which the Forum was established.

\section{Ireland and Europe: Nice as Watershed}

It is difficult to overstate the extent to which the result of the 2001 referendum represented a seismic shock to the body politic in Ireland. The country which, in opinion polls such as Eurobarometer, consistently produced the highest levels of support for European integration and, which more than any other member state, had made the EU work for it, now performed a volte face in rejecting the Nice Treaty. Despite the support of all four major political parties, Fianna Fáil, Fine Gael, Labour and the Progressive Democrats, as well as the support of the business community, the trade unions and most civil society groups, the electorate failed to endorse the Treaty. ${ }^{2}$

Whilst supporters of the Treaty picked over the bones of a failed campaign, some argued that it represented the cumulation of a growing antiEuropean feeling in Ireland, which had been evident from the earliest days of membership. After all, opposition to the integration project, tracked through the referendums held over the years, showed an increase in the No vote from 
17 per cent in 1972 to 30 per cent in 1987 (Single European Act), to 31 per cent in 1992 (Treaty on European Union), to 38 per cent in 1998 (Amsterdam Treaty), culminating in a decisive winning majority of 54 per cent in the Nice referendum of $2001 .^{3}$

Although government strategy had to address the concerns of the electorate, it was clear from a very early stage that a second referendum was on the cards. The pressure for ratification emanating from the EU and the Candidate States made that plain enough. For the government it was clear that some new form of public consultation and dialogue would be desirable as a response to the decision of the electorate and as a proactive move to establish the case for carrying the Treaty in a second referendum. The original idea of establishing a Forum, however, came from the opposition Labour party in December 2000, before the date of the referendum on the Nice Treaty had been set. In part this represented the party leadership's response to internal party criticism of the Nice Treaty, but it was also a proposal predicated on a negative appraisal of the modus operandi of the Referendum Commission which, because of a ruling in a landmark Supreme Court judgement, would be tasked with the responsibility of giving equal coverage to both sides of the argument in the upcoming referendum on the Treaty. ${ }^{4}$ In the case of an earlier referendum on abortion this had led to great confusion among voters. The Labour party argued that a wide-ranging and transparent dialogue on the full range of issues related to Irish membership of the EU would contribute to helping citizens better understand the issues and re-structure Ireland's European conversation on a more mature level. ${ }^{5}$ In the aftermath of the failure of the referendum in June 2001 the government accepted the proposal to institute a Forum and was quickly supported by all of the other political parties with the exception of main opposition party Fine Gael. 6

\section{The New Ireland Forum as a Model}

The government's task of putting the new deliberative structure in place was rendered somewhat easier by the existence of a domestic template. This was the New Ireland Forum from the 1980s. The brainchild of then Taoiseach Garret FitzGerald and SDLP leader John Hume, the New Ireland Forum was designed to "examine in a radical way the future development of all the people of the island". ${ }^{7}$ The four main constitutional nationalist parties on the island, Fianna Fáil, Fine Gael, Labour and the SDLP participated in the Forum. Unionist parties refused to attend, but some individual unionists presented their viewpoints. ${ }^{8}$ The New Ireland Forum Report was published on 28 May 1984 and was nothing if not radical in its findings, arguing that if a new Ireland was to emerge it could only do so via a new constitutional compact, one which would genuinely embrace all traditions on the island.

There are two important respects in which the New Ireland Forum stands as a model for the National Forum on Europe. The first is in the way it sought to lay out the facts about Northern Ireland in a comprehensive way that transcended party politics and ideological positions. The deliberations 
were characterised by a firm effort to 'face reality', with the issues laid out in clear and stark fashion. In the aftermath of the rejection of the Treaty of Nice, the National Forum on Europe would strive similarly to lay out all the facts relating to Irish membership of the EU in a structured format and in a relatively non-partisan climate.

A second parallel can be found in the preoccupation of both the New Ireland Forum and the National Forum on Europe with the concept of identity. Where the New Ireland Forum "set out on a conscious search for an Irish identity that would simultaneously embrace and transcend the conflicting identities of unionism and nationalism", 9 the Forum on Europe sought to understand Ireland's EU membership in the context of overlapping Irish and European identities. The New Ireland Forum brought together, for the first time since the division of Ireland in 1920, "elected representatives from North and South to deliberate on the shape of a new Ireland in which people of differing identities would live together in peace and harmony". ${ }^{10}$ The National Forum on Europe, in its deliberations, would grapple with the new duality of Irish identity, the new context that European membership brought to the old questions of identity and political community in Ireland. ${ }^{11}$ With the progressive deepening of the European Union and Irish interaction with the broad range of actors and institutions within the new transnational cooperative arenas, the 'Europeanisation' of Ireland and the 'socialisation' of Ireland into modern (or perhaps post-modern) European structures meant that identity would be to the fore of the Forum's deliberations. ${ }^{12}$

\section{Deliberative Democracy}

The work of the Forum, its modes of deliberation and development, pose interesting questions about the way in which EU politics is played out in individual member states. There is thus a need to analytically embed the Forum and its work in concepts of governance, collective decision making and models of representation and participation. Is there evidence that the Forum has contributed to the 'Europeanisation' of public policy in Ireland? Should the Forum be understood as a traditional elite-centred deliberative body or a genuine vehicle for citizen participation in EU affairs? This article argues that the Forum has enhanced both the range and scope of elite debate on EU issues whilst modestly encouraging an important measure of popular participation. This dualism is best understood under the rubric of deliberative democracy.

Under deliberative democracy, according to Dryzek "the essence of democratic legitimacy should be sought in the ability of all individuals subject to a collective decision to engage in authentic deliberation about that decision". ${ }^{13}$ The important point here is that of 'continuous' or 'processual' democracy. Individuals are not just content with exercising their right to vote every few years; large numbers of people now assert the right to scrutinise and hold to account governments and political elites through continuous political activity, which, as Magnette argues, "combine electoral rights with new kinds of patterns of participatory politics". ${ }^{14}$ These patterns can be 
highly differentiated, both universal and particular, ranging from cyberspace 'town hall' meetings to more traditional mid-term elections, to popular referendums and citizen initiatives and, as in California in 2003, a so-called 'recall election'. Other such patterns can be located in associative and interest group activity, broader collective movements such as the anti-globalisation movement and web-based discussion and deliberative fora. ${ }^{15}$ The common denominator that links these new participatory patterns is not just the potential they offer for empowering citizens vis-à-vis elites. It is that individuals should accept the decisions of elite bodies only if they can be publicly justified in very convincing terms. ${ }^{16}$

The "deliberative turn" in political science springs from "a renewed concern with the authenticity of democracy: the degree to which democratic control is substantive rather than symbolic, and engaged by competent citizens". ${ }^{17}$ Although even early classical scholars of democracy considered some forms of broad societal deliberation necessary and useful, what distinguishes current forms of deliberative democracy is the emphasis placed upon the necessity of equal and effective opportunity to participate in processes of collective judgment; ${ }^{18}$ what Nentwich terms "political opportunity structures" for citizens. ${ }^{19}$ This requires moving towards a much broader conception of the ownership over political decisions. Uhr argues that theories of deliberative democracy go beyond earlier approaches to participatory democracy "by specifying in greater detail the nature of the deliberative process in which citizens should be able to participate and of the importance of institutions of civil society to an effective deliberative process". ${ }^{20}$ The focus on ideals of public deliberation reflects the ambition of deliberative democrats to ground political decision-making "in norms of shared public reason". In addition, the very process of deliberation is one that holds out the possibility of preference change. In other words, the process of deliberation can and does result in actors changing their initial policy preferences in response to the arguments deployed in the discursive arena.

\section{Encouraging Popular Participation?}

The 'deliberative turn' can only be fully understood by engagement with models of popular participation in and oversight of public decisions. Deliberation can only remain rhetorical and superficial without meaningful popular engagement with political issues and processes of decision making. Benjamin R. Barber defines participatory politics as dealing with "public disputes and conflicts of interest by subjecting them to a never-ending process of deliberation, decision, and then action". ${ }^{21}$ The benefits for society of the greatest level of popular participation are taken for granted, as public ends are "literally forged through the act of public participation, created through common deliberation and common action". Participatory democracy strives for consensus, but it accepts the inevitability of conflict. The key to conflict resolution is the reconstruction of private or partial interests into publicly defensible norms through sustained deliberation. Barber is in agreement with deliberative democrats in arguing that the substantive meaning 
and content of political issues can and does change shape and direction when subjected to participatory processes.

In Western industrial democracies the social compact is built and dependent for its survival upon meaningful popular participation in political life. Barber argues "community grows out of participation and at the same time makes participation possible; civic activity educates citizens even as citizenship informs civic activity with the required sense of justice. Politics becomes its own university, citizenship its own training ground, and participation its own tutor". ${ }^{22}$ Citizens, thus, should "not only be given the opportunity to participate, but also be encouraged to do so ... civic participation has become the cornerstone of mass democracies". ${ }^{23}$

In reconciling the fact of relatively low popular participation rates with the fact of adequately functioning democracies, political scientists have enlarged their understanding of the political process and of the role of the average citizen in that process. The role of the citizen has evolved into something different from that envisaged by classical democratic theorists such as John Locke or John Stuart Mill. From a limited, narrowly-defined conception of society, and thus citizenship and expectations regarding participation (who may participate and what sort of channels are to be used), modern society has evolved a very differentiated and complex division of labour, not only in the economic sector but also in politics and government. Political roles have become highly disaggregated and specialised in what are now called governance systems. At the same time, participation has become far more diffuse.

Michael Nentwich, in contributing to the debate on the EU's much discussed 'democratic deficit', points out that across the EU "only indirect, non-binding and largely informal channels for the participation of citizens have been put in place so far". ${ }^{24}$ This is because citizens were only belatedly brought in to the process (with direct elections in 1979 introducing direct representation for the first time) and thus have not been at the centre of the European political system (understood here as a recognisable and unified polity) for the greater part of its history.

For Nentwich this means that what he terms the POS (Political Opportunity Structure) of the EU does not know any element of direct democracy in the narrow sense. ${ }^{25}$ Apart from elections to the European Parliament every five years, there are no direct ways for citizens to participate in European politics. The citizens therefore do not have an opportunity to play a direct role in agenda setting or to directly influence collective outcomes. Nowhere can be found a direct arena where questioning of representatives by citizens is possible. In addition given that EP elections are seen as 'second order elections' in many member states, voting as a mechanism for direct participation does not hold the same attraction as does voting in national elections. Only Denmark and Ireland consistently ratify EU treaties through popular referendums. This is a central element of the so-called 'democratic deficit', which it is alleged the EU suffers from.

Although the concept of a 'democratic deficit' is itself one that has been challenged by academics ${ }^{26}$ and public representatives, EU officials have, in recent years, conceded the substantive point regarding perception (if not 
reality). There have been many efforts made by the EU to 'bring in the citizens' i.e. encourage meaningful popular participation in the EU policymaking process. Most recently the White Paper on European governance defined participation as one of the five major principles of 'good governance'. Participation is supposed to enhance both the efficiency and legitimacy of European governance. Greater legitimacy in particular would flow from citizen participation of a more substantive kind. In Ireland the National Forum on Europe sought to encourage enhanced participation through two important mechanisms: public meetings where citizens could directly question public representatives, and secondly, through accepting and debating submissions from citizens and interest groups. For the first time this included a substantive online participatory process. Both deserve analysis under the rubric of deliberative democracy. Whilst these mechanisms augmented the structured deliberation among the political parties and civil society groups in the plenary sessions, they also contributed to an enhancement of popular participation in EU debate.

\section{Bringing in the Citizens: Public Meetings}

The idea of going on the road, of bringing the Forum to a local level, was that of the Chairman, Senator Maurice Hayes: "the idea of going around the country is a direct transplant of my experience of working in Northern Ireland, especially on the Patten Commission on policing. We did that in the north and the public were glad we did it and people were very receptive to it". ${ }^{27}$ His aim was "to provide a neutral space to enable people to hear all sides of the argument on Europe and to have their say, in their own areas". ${ }^{28}$

The public meetings were organised around separate themes. The policy areas and issues of concern that arose in the plenary sessions were largely confirmed and, indeed, reinforced in the course of the series of mini-fora. The four key issues to emerge were: issues of sovereignty and Irish neutrality; concerns about legitimacy, transparency and accountability of the EU system; the balance between large and small member states within an expanding Union; and the governance of the EU. The institution of these public meetings meant that, for the first time since joining the then EEC in 1973, Irish people had a dedicated and structured arena for expressing their concerns at a local level about the nature of Irish membership of the EU, and for impressing on public representatives the nature of their concerns.

The success of the public meetings might be gauged in a number of ways, chiefly the numbers of people attending, local media coverage, and success in engaging people in the Forum's work. The mini-fora did indeed generate substantial coverage in local and regional media. Editions of a weekly syndicated radio programme on the Forum's work were taken by up to seven stations, while a commissioned TV programme went out widely on the NTL cable television station in the greater Dublin area. The number of hits on the Forum website progressively increased to one thousand per week. ${ }^{29}$ Not unnaturally, the public meetings held in the run up to the second Nice Treaty referendum in October 2002 attracted the greatest number of citizens. At 
some venues in excess of 300 people turned up to listen to the arguments and put their points of view to the public representatives. ${ }^{30}$

The Chairman's promise to ensure that the Forum would constitute a 'listening shop' and not a 'talking shop' meant that the bulk of each meeting was given over to citizen concerns rather than political polemics from public representatives and interest groups. Thus, it could be argued that, through the public meetings in particular, the Forum represented a valuable exercise in encouraging meaningful and substantive popular participation in EU affairs. It may have represented a small step, but nevertheless was a significant break with the elite-centred conversation that had previously dominated discussion of the EU in Ireland. This part of the Forum's activities may well constitute a blueprint for the future - referendums on EU affairs will surely see a form of structured public dialogue centred on informing and engaging people through public meetings and information campaigns.

There was also something of a 'demonstration effect' in that the success enjoyed by the 'roadshow' demonstrated to politicians the value of 'going local' with European issues. Thus the Oireachtas (Irish Parliament) Committee on European Affairs sought to emulate the Forum by taking some of its meetings to regional venues. At the first regional meeting of the Committee in Mayo in early 2003 there was clearly a nod to the Forum as the Committee hosted a seminar with three local schools before embarking on its 'normal' business. Members of the Committee, convinced of the importance of publicising its work and legitimating its oversight and scrutiny functions, have declared their intention to hold Committee meetings in different parts of the country on a regular basis. The level of civic engagement demonstrated at the public meetings held by the Forum is consistently cited as evidence for the participatory potential of such mechanisms and an argument for a move away from the traditional elite-centred deliberative structures. ${ }^{31}$

\section{Submissions}

The second important mechanism for enhancing popular participation in the debate, but one also focused on elite deliberation, was the submission process. The Forum invited submissions from individual citizens, political parties, individual politicians, civil society groups, business organisations, trade unions, church organisations and the European Union institutions. On foot of an open invitation at the end of October 2001, over 60 submissions were received by the deadline of 1 December. ${ }^{32}$ Subsequently, submissions for oral presentation were selected by the Forum's steering committee. The two main subjects of interest were the Nice Treaty and its imperfections and EU enlargement.

The submissions ranged from the very detailed such as those on enlargement from Forfás ${ }^{33}$ and IBEC ${ }^{34}$, to the specific such as that from the Adelaide Hospital Society on EU health policies and the Irish Esperanto Society's plea that Esperanto be recognised as an official EU language. Individual citizens tended to comment on their interpretations of the Nice Treaty and what this meant for Ireland. Academic contributions focused mainly on 'big-picture' 
themes such as EU security policy and enlargement. The social partners focused, intentionally, on the areas of interest to them but also submitted views on enlargement and the merits of the Nice Treaty. The nature and concerns of the submissions certainly influenced the agenda of the Forum. ${ }^{35}$

The flow of submissions perhaps understandably slowed considerably after the Yes vote in October 2002. The Forum secretariat posted electronic submissions onto its website and thus established a sort of 'virtual Forum', a framework for receiving inputs from political circles and civil society and engaging the wider public with the substantive issues. This brought the public deeper into the ongoing dialogue in that those who could not attend plenary and regional meetings could at least get a sense of the main strands of debate by accessing the submissions. Thus, whilst it would be foolish to exaggerate the potential impact of the internet, in the case of the Forum it can be said to have made a modest positive contribution to enhancing popular participation and mobilisation in EU debate in Ireland.

\section{The Forum as an Elite Deliberative Body}

Some would argue that the Forum's work should be read cynically, as an attempt by the pro-European side to share the blame for the first Nice referendum defeat, as a cosmetic instrument designed to give the impression of 'listening' to the people, and as a panicked reaction to the breakdown of the 'permissive consensus' that had governed Irish attitudes to Europe since accession. That argument is undermined, however, by three observations.

First, those on the Eurosceptic side readily embraced the Forum as a vehicle for presenting their concerns about the direction of the European integration process. Had there existed some sort of conspiracy to ensure an overwhelmingly positive endorsement of Ireland's relationship with the EU and a Yes vote in the second referendum, the Eurosceptic political parties and civil society groups would almost certainly not have participated in the Forum. Ironically, it was Fine Gael, traditionally identified as the party most enthusiastic about EU membership, which alone decided to stay out. That decision, as has been seen, would later be reversed. Second, these groups have admitted that they were very fairly treated by the Chairman with respect to contribution times and the exchange of views, and that the Forum did constitute a genuine attempt to institute a far-reaching dialogue on Europe that had been absent through all the years of Irish membership of the EC/EU. ${ }^{36}$ Finally, and most crucially, the government's decision to maintain the Forum as a vehicle for EU debate - after the second referendum had seen the Nice Treaty carried - again suggests a genuine commitment to reconstituting European debate in Ireland on a more permanent footing.

If one disregards the cynical interpretations of the Forum a more nuanced set of observations can be produced. The analytical framework provided by deliberative democracy suggests a number of important ways in which the work of the Forum can be viewed as a departure from traditional Irish fora for public policy debate and in particular dialogue on Irish engagement with the European Union. In the first place the Forum contributed to collective 
decision making through a sustained and fully transparent elite and popular process of deliberation on the full range of issues surrounding Ireland's EU membership. Arguably the problem-solving capacity of the polity has improved somewhat in this area as a result. As deliberative democrats would suggest, it has introduced an element of 'processual' or continuous democracy that marks a distinct change from the previous norms of periodic or issue-specific dialogue centred on referendums, elections, or individual political controversies. The continuity of debate on European public policy is arguably, helping to underpin Ireland's changing relationship with the EU as it moves from the status of narrowly focused Cohesion state to a member state with a much wider concept of self-interest.

Second, the Forum's deliberations took place in a policy space largely independent of the coercive influence of government and the hitherto dominant pro-European lobby. For the first time in European debate in Ireland, the pro-Europeans found themselves opposed in a structured setting by an equally strong and vociferous set of actors. It could be argued that, over the years, with obvious economic benefits being derived from membership of the EU, the political establishment's perception of the Irish relationship with the EU became dangerously unbalanced and left little room for dissident opinion. The rejection of the Nice Treaty in June 2001 changed all this. Suddenly opposition to the EU was open, visible, and respectable. The Forum provided opponents of European integration an important public arena in which to legitimise themselves and their arguments, and to present themselves as equals of the pro-Europeans. In helping to problematise the concept of 'integration' itself opponents of the integration project also helped develop a more sophisticated Irish debate on Europe, by focusing especially on the non-economic dimensions of membership. The Forum thus constituted a valuable public space in which an alternative conception of Irish EU membership could be advanced and articulated.

Third, the institution and development of the Forum has helped to considerably widen the range of elite and civil society actors contributing to European debate. Earlier in this article comparison was made with the New Ireland Forum of the 1980s as a template for the Forum on Europe. The twenty-seven members and fourteen alternate members of that body consisted solely of party politicians. The National Forum on Europe, in contrast, embraced all the political parties in the Republic, the Irish MEPs, and, through its Special Observer Pillar, a much broader cross section of civil society, with organisations like the social partners, groups active in the Nice referendum campaigns and European affairs more generally, and the major churches and faiths. The inclusion of these groups reflects their new prominence in the Irish national debate on Europe, which has accelerated over the past decade. ${ }^{37}$ Also there as observers were registered political parties not represented in the Oireachtas ${ }^{38}$ and parties from Northern Ireland.

The wider dialogue made possible by the inclusion of the Special Observer Pillar was generally acknowledged. Ciaran Toland of Ireland for Europe, for example, asserted that the Forum Chairman, Senator Maurice Hayes "has increasingly looked beyond the political parties to the civil society groups like 
ourselves and sectoral groups, such as the churches and the Youth Council, for input. In particular the submission process for oral and written submissions was extremely positive, and provoked real engagement". ${ }^{39}$ This more inclusive concept of political and social dialogue is one that persuades some that the Forum managed to engender a more substantive sense of ownership over the intra-EU policy process that Ireland is part of. This accords with a core concept of deliberative democracy, that the health of the polity is substantially improved with the ability of civil society groups to articulate, aggregate and represent their own interests.

One notable development arising out of the Forum was the enhanced public profile attained by some of the smaller (and newer) political parties in Ireland. The dynamism exhibited by both Sinn Fein and the Green Party during the first referendum campaign stood in marked contrast to the complacency and sheer inertia of the pro-European parties. And, although they were ultimately to lose the argument on the Nice referendum, both parties used the Forum to their advantage by 'blooding' some of their prospective parliamentary candidates in the heat of political debate, and by building for these candidates a media profile that was put to good use in the general election campaign of $2002 .{ }^{40}$ In addition, both parties were very prominent at the regional meetings of the Forum, with a local presence that sometimes dwarfed that of the more established political parties.

Arguably, the Forum also changed the nature of elite thinking and discourse on Irish membership of the EU. The structure and development of the Irish political system and political culture historically militated against public representatives thinking about, engaging with and really 'internalising Europe', except in the most functional cost-benefit sense. Larry Siedentop in Democracy in Europe castigates European elites for making the "public case for Europe almost exclusively in economic terms. In their pronouncements, the elites of Europe have fallen victims to the tyranny of economic language at the expense of political values such as the dispersal of power and democratic accountability. Increasingly, we find ourselves worshipping at the altar of economic growth rather than citizenship". ${ }^{41}$ In the Irish case, however, a number of features of the political culture have long exacerbated the problem.

The most important of these has been the ingrained parochialism and extravagant clientelism which, for many observers, has been the significant distinguishing characteristic of Irish politics. ${ }^{42}$ The structure of the system did not encourage public representatives to think seriously about European issues in any sustained way. The nature of the multi-seat proportional representation electoral system (PRSTV) in particular militated against the Dáil developing as a strong Parliamentary Chamber; as Joe Lee suggests it has "exerted a paralytic influence on many politicians". ${ }^{43}$

As a consequence of the PRSTV system and the competitive nature of intra-party competition within individual constituencies which it encouraged, public representatives have traditionally been exclusively concerned with 'delivering for the locality' and watching their backs against local party rivals; the obvious consequence of this is that for too long politicians have 
been oblivious to European and international politics. The so-called 'dual mandate', which allowed public representatives to simultaneously hold the offices of member of parliament and member of the local county council, also contributed to an excessive focus on constituency issues, to the neglect of EU issues, save for issues surrounding the delivery of the structural or cohesion goodies.

There is strong evidence to suggest that the Forum has helped to counter these tendencies by providing a sustained public debate on EU issues that has informed public representatives and brought 'Europe' into the mainstream of Irish political debate for the first time. From the outset the Forum's discourse has been embedded in a pan-European narrative. With speakers from France, Slovenia, Malta, the Czech Republic, Denmark, the UK, Belgium, Sweden, Austria and Poland, as well as members of the European Commission and the President of the European Parliament, the Forum also impressed on participants the extent to which Ireland's future is interlinked with its neighbours and partners in Europe. Thus a sense of 'networked Europe' and 'partnership Europe' was communicated consistently to the Forum members and observers. Those with isolationist and nationalist tendencies were confronted with evidence of the importance of the multifaceted and well-developed relationships which have grown up around the EU. Thus the Forum, through its various modes of deliberation, has contributed further to the Europeanisation of Irish public policy.

Similarly the Forum contributed to an enriched understanding of what the enlargement process entails. With testimony from a large number of senior politicians and scholars from the Candidate countries, the Forum contributed to better informing the political classes about the nature of the transformation process in Central and Eastern Europe, the difficulties faced in meeting the criteria laid down in the acquis communautaire, and the attitudes and disposition of potential future allies within the EU family. ${ }^{44}$ The sheer number of plenary sessions dedicated to enlargement issues is indicative of the importance attached by the Forum to informing political and societal actors about the different dynamics of the enlargement process.

A fourth important observation is that the Forum's participative instruments have also functioned as a mechanism for achieving some sort of balance between consensus and cleavage on European issues in Ireland. In this sense it accords with the emancipatory prescriptions of Almond and Verba. ${ }^{45}$ Agreement on the larger principles which, it is argued, govern Ireland's relationship with the European Union, even if they are somewhat vague and normative, have helped to bridge the cleavages which emerged during the first Nice Treaty referendum. The Forum as an instrument of bridge building in effect has facilitated movement toward consensus. This is not to overstate the importance of the Forum's work. It is, however, to argue that it can be credited with some important achievements. The Forum undoubtedly helped to ease tensions between the pro and anti Nice sides in the wake of the rejection of the Treaty in 2001. By providing an arena for structured dialogue in which a healthy exchange of views could take place, the Forum helped ensure that the fissures created by Nice I were not further 
exacerbated. The sharp polarisation revealed by Nice I continued to exist but the edges were blunted somewhat.

Finally, it should be noted that the Forum also made an impact with EU officials and those interested in finding mechanisms for bridging the democratic deficit, for bringing Europe 'closer to the citizen' in the future. Close attention was paid to its deliberations by think thanks such as the Centre for European Reform and the European Policy Centre. It may even serve as a model that is taken up by other European states as they grapple with similar issues in managing their relations with the EU. Polish Foreign Affairs Minister Wlodzimierz Cimoszewicz told the Forum that "just over a month ago we established in Poland our own Forum on the future of Europe, which functions in a similar formula to yours. The Polish Forum meets in various places around the country to discuss the future of Europe with the public at large". ${ }^{46}$ The importance of the signals sent out by the Forum to the Candidate countries was underlined by the Chairman in his Second Report on the Forum's work: "the frequent presence of a large number of the Diplomatic Corps, including notably ambassadors from Candidate countries, ensured that the voice of the Forum was heard beyond Irish shores". ${ }^{47}$

\section{The Forum as a Vehicle for Popular Participation}

If the evidence suggests that the Forum has contributed significantly to a reconfiguration of elite debate in Ireland on European issues, a much more modest impact on popular participation can be evinced. The argument presented here suggests that the Forum did not really meet the expectations of those who hoped for meaningful popular participation. Whilst one could argue that the institution of the Forum helped in forging a more participative culture in Ireland, and complemented other measures such as the re-constitution of the Oireachtas Joint Committee on European Affairs in a strengthened capacity ${ }^{48}$ (designed to ensure greater oversight of EU legislation), it is debatable whether ordinary citizens responded in any significant way. Whilst turnout in the second Nice referendum increased significantly, by a factor of one third, from 35 per cent to 49 per cent (a very significant factor in the outcome given that almost all of these 'returning' voters voted to accept the Treaty), a turnout figure short of 50 per cent hardly represents an indication of an engaged citizenry and robust participation. Certainly, the turnout figure compares very poorly to those witnessed in Denmark on European referendums there over the past decade ${ }^{49}$.

If one moves away from the 'pure' concept of participation and modifies it to embrace the idea of giving people a clearer sense of ownership over the political process, then the Forum can be credited with some successes. If the argument is about a greater visibility for Europe and EU related issues and bridging the 'information gap' then the Forum must be viewed more positively. Professor Richard Sinnott's analysis of the 2001 referendum showed that a mere 8 per cent of people felt they had a good understanding of what the Treaty was about and a further 28 per cent that they understood some of the issues but not all those involved. This meant that effectively two thirds of 
the electorate admitted to not understanding the Treaty. ${ }^{50}$ Thus addressing the information deficit became a crucial plank of Government strategy.

The Forum represented one important part of that strategy. Citizens who spoke at the public meetings acknowledged that the government had at least paid attention to concerns and the Forum represented one important mechanism for disseminating information and encouraging debate. Professor Sinnott's report on the second referendum confirmed that the Government's information campaign, which was far superior to that during the first referendum, "struck a chord with a substantial number of voters". ${ }^{51}$ In the first campaign, 44 per cent of voters claimed they did not vote because they lacked understanding of and information on, the Treaty. Just 26 per cent gave the same excuse after the second referendum. The crucial point here is that the Forum itself emerges rather well from Sinnott's analysis. Nearly 25 per cent of respondents found its work valuable, while nearly 50 per cent were at least aware of its work. That said, however, "just 8 per cent of people believe they know appreciably more about the European Union itself". ${ }^{52}$ The importance of keeping people informed was underlined by former Labour party leader Ruraí Quinn: "it demonstrates the need for a sustained information campaign throughout all the institutions of the State on an ongoing basis about Europe". 53

Lawrence Pratchett points out that there is nothing new about popular participation in politics as a supplement to the traditional forms of representative democracy. ${ }^{54}$ However, he argues that recent years have seen the introduction of a range of more innovative participatory instruments and these have begun to change the nature and impact of popular participation. Insofar as these new patterns of participation contribute to the opening up of politics, democratic practice is enhanced. The National Forum on Europe represents at least a step in the right direction in Ireland, and offers the potential for empowering citizens to a much greater degree in the years ahead.

\section{Conclusions}

The arguments presented here regarding the impact of the National Forum on Europe can only be understood in the context of Ireland's changing relationship with Brussels. The economic renaissance that has changed the face of the country over the past decade has also altered the contours of debate on the nature and merits of EU membership. The rejection of the Nice Treaty in 2001 made manifest the new concerns regarding sovereignty, institutional issues and the future trajectory of the European integration process. With the failure of the referendum the Irish government moved to tackle these concerns by instituting a new public arena for dialogue and deliberation. The Forum represented an entirely novel approach to consideration of European affairs in Ireland, and as such, an acknowledgement that the old era of 'permissive consensus' on EU issues had gone.

The evidence suggests that the Forum has successfully widened the scope and substance of Irish elite attitudes to Europe. Most importantly, it has helped shift the emphasis from functional cost-benefit considerations related 
to receipts from the Common Agricultural Policy (CAP) and structural funding to a more broad-based and sophisticated analysis. It has succeeded in that by engaging a wider and more inclusive group of societal actors in European debate and, to a lesser extent, by creating structures that have facilitated limited popular participation in its deliberations. On that basis one can certainly claim that the Forum represents a small but not insignificant advance in the democratic oversight (both elite and popular) of EU issues in Ireland, and perhaps a model for other member states in their efforts to widen the scope of domestic participation in EU affairs.

\section{Acknowledgement}

This paper was first presented at a conference on 'Ireland: The Nice Treaty Referendums, Enlargement and the Future of Europe' held at the Liverpool Hope University, 22 February 2003. The author thanks the participants for their comments. Thanks also to Maura Adshead, Richard Holland, Niall Keane, Walter Kirwan, John Logan, Noel Mulcahy, Dolores Taaffe and three anonymous reviewers for their constructive criticism.

1. National Forum on Europe (NFOE No. 1) (2002), p. 6.

2. For an analysis of the Nice Treaty referendums held in Ireland see O’ Brennan (2003).

3. Sinnott (2001).

4. The Referendum Commission was set up by the Referendum Act, in response to the McKenna Judgement (McKenna v. An Taoiseach No. 21995 Irish Law Reports 37) after an Irish MEP, Patricia McKenna of the Green Party successfully argued that the government should not be allowed to use public money to fund partisan referendum campaigns. The Referendum Commission's primary role is to explain the subject matter of the referendum to the voters. It is tasked with ensuring that each side in a referendum campaign has equal opportunity to put their case.

5. Interview, Ruraí Quinn, former leader of the Labour Party, Dublin, 9 July 2003. The author thanks an anonymous reviewer for input on this point also.

6. Fine Gael, although it campaigned in favour of ratification of Nice in the first referendum, decided not to participate initially in the Forum. Party leader Michael Noonan saw the Forum as a cynical exercise in political chicanery by a government desperate to deflect criticism for the catastrophic failure experienced with the failed referendum. Mr Noonan's view, however, was not widely shared by members of the Fine Gael front bench who were not consulted on the decision to stay out. $\mathrm{Mr}$ Noonan's successor Enda Kenny reversed the decision immediately on taking up the leadership of Fine Gael in June 2002. Interviews: Bernard Durkan TD, Michael Finnucane TD, Nora Owen TD, Dublin, April/May 2002.

7. Keogh (1994), p. 368.

8. Lee (1989), p. 675.

9. Lee (1989), p. 675.

10. New Ireland Forum Report, 1984.

11. See the Report of Proceedings for the National Forum on Europe for 28 February 2002 where there is a comprehensive examination of questions related to culture and national identity (National Forum on Europe (NFOE No. 14) (2002)).

12. The intensive nature of interaction was referred to explicitly by Senator Hayes in his opening remarks at the launch of the Forum in Dublin Castle on 18 October 2001: "On Monday and Tuesday of this week, Ireland hosted an important visit by the President of the European Parliament, Madame Fontaine; yesterday, senior government figures held high-level consultations in Brussels with Commissioner Prodi; tomorrow, the Taioseach and the Minister for Foreign Affairs will represent this country at a summit of EU Heads of Government in Ghent, and of course, throughout all this, 


\section{John O’Brennan}

Ireland hosts the Presidency of the UN Security Council, in which role we have an obligation to represent the shared values and principles of Irish and EU Common Foreign Policy in the organisation charged with the maintenance and promotion of international peace and stability." (National Forum on Europe (NFOE No. 1) (2002), p. 7.

13. Dryzek (2000), p. 1.

14. Magnette (2003), p. 151.

15. For an interesting analysis of the possibilities afforded by new patterns of online participation in public debate, see Ward, Gibson \& Lusoli (2003).

16. Warren (2002), p. 174.

17. Dryzek (2000), p. 1.

18. Warren (2002), p. 174.

19. Nentwich (1996).

20. Uhr (2002), p. 189.

21. Barber (1984), p. 151.

22. Ibid., p. 152.

23. Magnette (2003), p. 152.

24. Nentwich (1996).

25. Ibid.

26. See, for example, Moravscik's effort to "reassess legitimacy" in the EU, in Moravscik (2002).

27. Sunday Independent, 1 September 2002.

28. Irish Times, 4 September 2002.

29. Information supplied by the Forum secretariat.

30. Information supplied by the Forum secretariat.

31. Interview, Jim Mulkerins, Clerk to the Oireachtas Joint Committee on European Affairs, 9 July 2003.

32. To view the full range of submissions visit the Forum's website: http://www.forumoneurope.ie

33. Ireland's national policy and advisory board for enterprise, trade, science, technology and innovation.

34. Irish Business and Employers Confederation.

35. National Forum on Europe (NFOE No. 1) (2002), p. 19.

36. Interview, Anthony Coughlan, the National Platform, Dublin, 23 April 2002.

37. Laffan (1999), p. 100.

38. The Irish Parliament.

39. Sunday Independent, 1 September 2002.

40. On the Sinn Féin side Aengus Ó'Snodaigh and Mary Lou MacDonald both contributed effectively and regularly to debate. For the Greens, Eamon Ryan, Dan Boyle, Paul Gogarty and Ciaran Cuffe all were elected to the Dáil in the June 2002 election.

41. Siedentop (2001), p. 217.

42. Hussey (1993), p. 57.

43. Lee (1989) p. 546. On patronage, personalism and clientalism in Irish political culture see: Carty (1981), Chubb (1963), Farrell (1983). The author thanks Maura Adshead for advice on literature.

44. See, for example, the debate on enlargement issues contained in National Forum on Europe (NFOE No. 8) (2002).

45. Almond and Verba (1963).

46. National Forum on Europe (NFOE, No. 8) (2002), p. 51.

47. National Forum on Europe (NFOE, Second Report) (2002), p. 6.

48. The role of the European Affairs Committee changed significantly in the summer of 2002. The European Union (Scrutiny) Act 2002 now requires the government to send to the Committee in advance all proposals for regulations and directives within four weeks of their being received by a government department. A sub-committee was established which meets every two weeks to deal specifically with this process of scrutiny. The sub-committee then decides whether or not to recommend further scrutiny. In 2003 the sub-committee examined approximately four hundred draft regulations or directives. In about 30 per cent of cases the proposed measures were referred to the relevant sectoral committees within Parliament. A second important change introduced by the Act relates to the Minister for Foreign Affairs. He/she is now required to come before the committee each month 
before going to the General Affairs Council (GAC). The committee considers the agenda for the GAC with him/her and members ask questions or raise issues as they see fit. See the exchange of views between the European Affairs Committee and its Swedish equivalent for more on the nature of the changes introduced at: http://www.irlgov.ie/oireachtas/frame.htm

49. Comparison with Denmark is particularly revealing. In the 1972 referendum on accession, turnout was extraordinarily high after a very heated campaign at 89.9 per cent. The referendum on the Single European Act in February 1986 saw a drop in turnout to 76.6 per cent. The referendum on the Maastricht Treaty in June 1992 saw a turnout of 83 per cent and the second referendum 86.5 per cent. The Danish referendum on membership of the Single Currency in September 2000 saw a turnout of 87.8 per cent. In Ireland turnout at European referendums has varied from a high of 70.9 per cent in 1972 to a low of 35.4 per cent in 2001.

50. Sinnott (2001).

51. Sinnott in Eurobarometer (2003); Irish Times, 27 February 2003.

52. Ibid.

53. Irish Times, 27 February 2003.

54. Pratchett (1999), p. 616.

\section{References}

Almond, G. \& Verba, S. (1963) The Civic Culture (Princeton, NJ: Princeton University Press).

Barber, B. (1984) Strong Democracy: Participatory Politics in a New Age (Berkeley, CA: University of California Press).

Brown, T. (1985) Ireland: A Social and Cultural History 1922-1985 (London: Fontana Press).

Carty, R. K. (1981) Party and Parish Pump: Electoral Politics in Ireland (Waterloo, Canada: Wilfred Laurier).

Chubb, B. (1963) Going about persecuting civil servants: the role of the Irish parliamentary representative, Political Studies 10(3), pp. 272-286.

Drysek, J. (1990) Discursive Democracy (Cambridge: Cambridge University Press).

Drysek, J. (2000) Deliberative Democracy and Beyond, Liberals Critics, Contestations (Oxford: Oxford University Press).

Eurobarometer (2003) Eurobarometer 58, National Standard Report: Irish Public Opinion and European Integration. Available at http://www.europa.eu.int/comm/public_opinion/archives/eb/ eb58/eb58_ireland.pdf

Farrell, B. (1983) Ireland: from friends and neighbours to clients and partisans: some dimensions of parliamentary representation under PRSTV, in: V. Bogdanor, Coalition Government in Western Europe (London: Heinmann).

Hussey, G. (1993) Ireland Today: Anatomy of a Changing State (Dublin: Town House and Viking Press).

Irish Business and Employers Confederation (IBEC) (2002) Submission to the National Forum on Europe: EU Enlargement, 31 January (Dublin: IBEC).

Irish Law Reports (1995), McKenna v. An Taoiseach (No. 2), No. 37.

Joint Committee of European Affairs (2003) Text from the Visit by the Swedish Parliamentary Delegation. Available at http://www.irlgov.ie/oireachtas/frame.htm

Keogh, D. (1994) Twentieth-Century Ireland: Nation and State (Dublin: Gill and MacMillan).

Laffan, B. (1999) The European Union and Ireland, in: N. Collins (Ed.), Political Issues in Ireland Today, second edition, pp. 89-105 (Manchester: Manchester University Press).

Magnette, P. (2003) European governance and civic participation: beyond elitist citizenship? Political Studies, 51, pp. 144-160.

Milbrath, L. W. (1965) Political Participation: How and Why do People get Involved in Politics? (Chicago, IL: Rand McNally).

Miller, D. (1993) Deliberative democracy and social choice, in: D. Held (Ed.), Prospects for Democracy, pp. 74-92 (Oxford: Polity).

Moravscik, A. (2002) In Defence of the 'democratic deficit': reassessing legitimacy in the European Union, Journal of Common Market Studies, 40(4), pp. 603-624.

National Forum on Europe (NFOE No. 1) (2002) Official Launch of the National Forum on Europe, Report of Proceedings 18 October 2001, Number 1 (Dublin: Government Publications Office). 


\section{John O’Brennan}

National Forum on Europe (NFOE No. 2) (2002) The Enlargement Process: A Geo-Political Overview, Report of Proceedings, 25 October 2001, Number 2 (Dublin: Government Publications Office).

National Forum on Europe (NFOE No. 5) (2002) Enlargement and Trade and Investment, Report on Proceedings, 22 November 2001, Number 5 (Dublin: Government Publications Office).

National Forum on Europe (NFOE No. 6) (2002) Environmental and Social Perspectives on an Enlarging Europe, Report on Proceedings, 29 November 2001, Number 6 (Dublin: Government Publications Office).

National Forum on Europe (NFOE No. 7) (2002) The Effects of Enlargement on Agriculture and the Food Industries, Report on Proceedings, 6 December 2001, Number 7 (Dublin: Government Publications Office).

National Forum on Europe (NFOE No. 8) (2002) Review of Enlargement Discussion, Report on Proceedings, 13 December 2001, Number 8 (Dublin: Government Publications Office).

National Forum on Europe (NFOE No. 10) (2002) Ireland and an Enlarging Europe After Laeken: What are the Choices? Report on Proceedings, 1 February 2002, Number 10 (Dublin: Government Publications Office).

National Forum on Europe (NFOE No. 11) (2002) Hearing of Presentations Based on Submissions Received, Report on Proceedings, 11 February 2002, Number 11 (Dublin: Government Publications Office).

National Forum on Europe (NFOE No. 12) (2002) Decision-Making in Europe, Report on Proceedings, 14 February 2002, Number 12 (Dublin: Government Publications Office).

National Forum on Europe (NFOE No. 13) (2002) EU Common Foreign and Security Policy, Report on Proceedings, 21 February 2002, Number 13 (Dublin: Government Publications Office).

National Forum on Europe (NFOE No. 14) (2002) The EU Social Model / Cultural and National Identity, Report on Proceedings, 28 February 2002, Number 14 (Dublin: Government Publications Office).

National Forum on Europe (NFOE No. 15) (2002) Role of the European Commission, Report on Proceedings, 7 March 2002, Number 15 (Dublin: Government Publications Office).

National Forum on Europe (NFOE No. 16) (2002) The Joint Oireachtas Committee on European Affairs and Combdhail Naisiunta na Gaeilge: Hearings of Presentations Based on Submissions Received, Report on Proceedings, 12 March 2002, Number 16 (Dublin: Government Publications Office).

National Forum on Europe (NFOE No. 17) (2002) The Role of National Parliaments, Report on Proceedings, 14 March 2002, Number 17 (Dublin: Government Publications Office).

National Forum on Europe (NFOE No. 18) (2002) Ireland and Nice - What Path to Take? Report on Proceedings, 21 March 2002, Number 18 (Dublin: Government Publications Office).

National Forum on Europe (NFOE) (2002) The First Phase of Work of the National Forum on Europe October 2001 to January 2002, Chairman's Report (Dublin: Government Publications Office).

National Forum on Europe (NFOE) (2002) The Second Phase of Work of the National Forum on Europe, February to March 2002, Chairman's Report (Dublin: Government Publications Office).

Nentwich, M. (1996) Opportunity Structures for Citizens' Participation: The Case of the European Union, European Integration online Papers. Available at http://eiop.or.at/eiop/texte/1996-001a.htm

O' Brennan, J. (2003) Ireland's return to 'normal' EU voting patterns: the 2002 Nice Treaty referendum, European Political Science, 2(2), Spring, pp. 5-14.

Parry, G., Anderson, B. et al. (1972) Participation in Politics (Manchester: Manchester University Press).

Pateman, C. (1970) Participation and Democratic Theory (Cambridge: Cambridge University Press).

Pratchett, L. (1999) New fashions in public participation: towards greater democracy? Parliamentary Affairs, 52(4), October, pp. 616-633.

Scharpf, F. (1999) Governing in Europe: Effective and Democratic? (Oxford: Oxford University Press).

Siedentop, L. (2001) Democracy in Europe (London: Penguin).

Sinnott, R. (2001). Attitudes and Behaviour of the Irish Electorate in the Referendum on the Treaty of Nice, Flash Eurobarometer Survey for the European Commission (Dublin: Institute for the Study of Social Change, UCD).

Sinnott, R. (2002) Cleavages, parties, and referendums: relationships between representative and direct Democracy in the Republic of Ireland, European Journal of Political Research, 41(6), pp. 811-826.

Uhr, J. (2001) Testing deliberative democracy: the 1999 Australian Republic referendum, Government and Opposition, 35(2), pp. 189-210. 
Ward, S., Gibson, R., \& Lusoli, W. (2003) Online participation and mobilisation in britain: hype, hope and reality, Parliamentary Affairs, 56(4), October, pp. 652-668.

Warren, M. (2002) Deliberative democracy, in: A. Carter \& G. Stokes (Eds) Democratic Theory Today: Challenges for the Twenty First Century, pp. 173-01 (Cambridge: Polity).

Weale, A. \& Nentwich, M. (eds) (1998) Political Theory and the European Union: Legitimacy, Constitutional Choice and Citizenship (London: Routledge). 